growth and yield responses of celery to Liriomyza trifolii. Entomol. Expt Appl. 38:15-21.

Trumble, J.T. and N.C. Toscano. 1983. Impact of methamidophos and methomyl on population of Liriomyza species (Diptera: Agromyzidae) and associated parasites in celery. Can. Entomol. 115:1415-1420.

Wene, G.P. 1955. Effect of some organic insecticides on the population levels of the serpentine leafminer and its parasites. J. Econ. Entomol.
48:596-597.

Zehnder, G.W. and J.T. Trumble. 1984. Host selection of Liriomyza species (Diptera: Agromyzidae) and associated parasites in adjacent plantings of tomato and celery. Environ. Entomol. 13:492-496.

Zehnder, G.W. and J.T. Trumble. 1985. Sequential sampling plans with fixed levels of precision for Liriomyza species (Diptera: Agromyzidac) in fresh market tomatoes. J. Econ. Entomol. 789:138-142.

\title{
Minimizing Pesticide Use in a Vegetable Management System
}

\author{
Christine Taylor Stephens \\ Department of Botany and Plant Pathology, Michigan State University, East Lansing, MI 48824
}

This nation is moving from an era of heavy dependency upon routine pesticide sprays to an age when more attention will be given to precision-timed application of fungicides and to implementation of alternative strategies to control plant pathogens. For more than a decade, terminology such as biological control, soil suppressiveness, hypovirulence, integrated pest management, and genetic engineering has been associated with research conducted in the discipline of plant pathology. Some of these disease control strategies are finally coming on line; others are still under development. Today, more than ever before, the alternative strategies are being taken seriously.

There are several reasons for this change. The first is concern for the environment. Newspapers are full of articles on toxic waste sites, increased rates of cancer in neighborhoods with contaminated soils, and linkages between pesticides and cancer. Concern by the American public has prompted new restrictive legislation to deal with chemical waste products. Past mishandling of chemical waste products continues to haunt us and slows present and future pesticide development and use.

Second, alternative control strategies are looking attractive because we are losing many of our important broad-spectrum fungicides. Recall the rumors circulating several years ago that $50 \%$ to $60 \%$ of the currently registered fungicides would be taken off the market within 5 years. These predictions were perceived as gross exaggerations not to be taken seriously. A review of the cancellations occurring over the past 2 years shows that the predictions may be uncomfortably close to reality.

In addition to cancellations, another concern related to fungicide use is that many new fungicides are specific for certain groups of plant pathogens. In general, they are more effective than broadspectrum fungicides on the few plant pathogens they control, but totally ineffective on non-target fungi. Bayleton is a representative example of these new materials. It is highly active against rust and powdery mildew fungi. While Bayleton is an excellent material for controlling powdery mildew on cucurbits, it is ineffective against the other leaf-spotting and fruit-rotting organisms that commonly affect this crop. Bayleton and other materials like it should not be considered as replacements for more traditional broad-spectrum materials, but rather as effective additions to the arsenal of chemical weapons.

The issue of farm profitability may also help explain renewed interest in alternative strategies. Profit margins are not as large as they were 10 years ago for most vegetable crops. Growers have discovered that use of a more integrated approach to controlling plant pests, rather than a routine 7-day pesticide spray schedule, may reduce costs and increase profit margins.

The first objective of this paper is to present several strategies researched over the past few decades that have made the transition from theory to application and are now being used on the farm. Second, several new and. conceptually different strategies in pest control will be presented. These strategies represent ideas and thoughts that are just now being researched at a basic level in the laboratory and may affect the farm in 10 to 15 years.

\section{Biocontrol agents}

Biological control of plant pathogens accomplished through traditional host plant resistance and cultural practices has been working for decades and continues to be the predominant disease control strategy. Biological control accomplished through introduction or encouragement of microorganisms antagonistic to plant pathogens has been slower to develop (Cook, 1981). Much progress has been achieved on the identification of antagonistic microorganisms that may be used as biocontrol agents. However, it is far easier to observe microbial antagonists in a petri plate than to make the organisms work as biocontrol agents in field situations. Research leading to a hypothesis as to how these organisms might function has helped identify the necessary desirable attributes of a biocontrol agent. First, an organism adapted to the environment of the pathogen has the best chance to control the disease successfully (Baker and Scher, 1987). For example, a nonpathogenic species of Pythium has been found that will colonize the sporangia of (and thereby suppress) a pathogenic species of Pythium that incites cucumber damping-off (Lifshitz et al., 1984). The use of a taxonomically related microorganism increases the chance of successful biological control as the organism is likely to occupy a similar ecological niche.

Second, to use biocontrol agents, we must be able to apply them economically and efficiently without losing effectiveness. The organism must be able to survive agricultural introduction in place of pesticides by methods such as seed application, overhead watering, and in-furrow applications (Baker and Scher, 1987). For example, research is currently being conducted on selecting desiccation-resistant fluorescent pseudomonades that can be introduced onto seeds. Other studies have focused on methods of preparing bacteria in such a way that survival is increased. A dry gum-talc formulation has been described that permits successful introduction of pseudomonades onto seeds (Suslow and Scroth, 1982).

Third, our biocontrol agent must be compatible with other methods of controlling pests (Baker and Scher, 1987). If pesticides must be used on the crop to protect it against other pathogens, the biocontrol agent needs to be compatible with those fungicides. Researchers have found a Trichoderma sp. isolate that is effective in suppressing Pythium damping-off in carnation. However, it was necessary to use benomyl in the system to control Rhizoctonia damping-off. Unfortunately, the biocontrol agent was sensitive to benomyl. The situation was resolved by the selection of a benomyltolerant strain of the biocontrol agent (Papavizas et al., 1982).

Another desirable characteristic of a successful biocontrol agent is the suppression of disease pathogens by a combination of several methods. Biocontrol agents suppress pathogens by such means as competition, antibiosis, and exploitation (Baker and Scher, 1987). Examples of antagonistic organisms using each method of control have been published. Competition for Fe has been shown to be one of the ways in which fluorescent pseudomonades suppress pathogenic soil microbes (Scher and Baker, 1980). These bacteria produce Reacquiring compounds called siderophores, which have a higher Febinding content than the siderophores of many fungi, making them 
more competitive for Fe (Garroway and Evans, 1984). Certain strains of bacteria have also been shown to produce antibiotics that inhibit the growth of various soil microorganisms. Recent work by Rothrock and Gottlieb (1984) has shown that a Streptomyces sp. produces the antibiotic geldanomycin, which inhibits the growth of $R$. solani in soil.

Trichoderma, a fungus that biologically controls several soilborne plant pathogens, has been shown to actively invade $R$. solani and P. ultimum mycelia (Chet et al., 1981). The production of a lytic extracellular chitinase enzyme appears to be a key component of this process (Elad et al., 1982). An ideal biocontrol agent might possess two or more methods of attacking the pathogen.

Of the many fungi and bacteria that have been screened as potential biocontrol agents, the fluorescent Pseudomonas spp. and Trichoderma spp. seem to be the most promising. They fit many of the criteria just discussed. Their antagonistic activity has been well-established for years. Current research focuses on methods of preparing large quantities of these organisms and extending their activity against a, wider array of pathogens by mutant selection. Mutants are also being sought that are resistant to commonly used bactericide and fungicides. Although much basic research remains to be done on these two groups of organisms and other potential antagonistic microorganisms, attention also needs to be given to completing the process of product development. Contractual funding arrangements between companies willing to market the biofungicides and researchers knowledgeable of the biology of these biocontrol agents may push product development along.

In 1988, Dagger G, the first commercially registered biofungicide, was introduced to control damping-off on cotton caused by the pathogens Pythium and Rhizoctonia spp. (Biocontrol Committee, 1988). Dagger G contains the living bacterium Pseudomonas fluorescens formulated in an organic granule carrier. The product is applied at $17 \mathrm{~kg} \cdot \mathrm{ha}^{-1}$ in the furrow using traditional planter box equipment. The material is compatible with insecticides and herbicides routinely used in a pest management program for cotton. Dagger $G$ appears to have multiple modes of action against the damping-off pathogens, including competition for Fe and other nutrients, as well as production of a low level of antibiotics (Brosten, 1988).

\section{Disease resistance}

Of the strategies used to control plant pathogens, disease resistance remains the most popular because a) it is the least expensive (no pesticides or energy cost), b) it is of low risk to humans and the environment, and c) it is a dependable form of control. However, incorporating disease resistance into commercial crops by conventional plant breeding has some limitations. One of those is that sexual crossing entails a massive random reassortment of two complete genomes, which makes extensive backcrosses a necessity (Willmitzer, 1987). The use of tissue culture technologies maybe a means to circumvent the backcrossing process by selecting for disease resistance from susceptible horticulturally desirable plant cultivars. Researchers have discovered that the process of culturing explants and regenerating plants can yield somaclones that differ slightly from the parent material (Larkin and Scowcroft, 1981). The variation noted in regenerated plants has been termed somatic variation, and is now seen by plant pathologists as a method of releasing plant cultivars with increased resistance to various plant diseases (Daub, 1986). At least 18 disease-resistant lines obtained through tissue culture have been reported (Daub, 1986). Several researchers have selected for Fusarium oxysporum f. sp. lycopersicum resistance in tomato, and a new type of resistance to tomato mosaic virus has been discovered using somaclonal screening procedures. (Barden et al., 1986). Other vegetable crops in which increased levels of resistance to important diseases have been reported in the past 3 years include celery (Wright and Lacy, 1988) and lettuce (Brown et al., 1986).

To date, at least two cultivars derived from somaclonal variation have been released. One is a sugarcane cultivar that carries increased resistance to Fiji disease; the other is a sweet potato cultivar that has a darker, more-stable skin color than currently used culti- vars, a desired quality trait (Daub, 1986). Several other vegetable cultivars with somaclonally derived resistance are in the developmental stage. The costs of developing cultivars by use of somaclonal variation will probably not differ much from conventional breeding. Funding will likely come from contractual arrangements between researchers and high-technology seed companies interested in marketing the germplasm. Some of the larger companies already have their own researchers using the technique. Use of disease-resistant cultivars, regardless of how they were developed, has not been incompatible with other approaches to plant disease control.

\section{Pesticides}

Routine applications. Pesticides are currently the most common tool for controlling disease losses and they will continue to play an important role in the future. In many vegetable crops, fungicides and/or bactericide are applied on a routine 7- to 10-day basis. Growers initiate a spray program early in the growing season and extend it as near as possible to harvest. However, for certain commodities, integrated pest management principles are being implemented by the use of scouting programs. In these IPM programs, scouts routinely monitor fields to determine when specific plant pests reach economic thresholds. Pesticides are applied based on the findings of the scouts and weather forecasts. In other systems, computer-driven disease forecasting models have been devised that are based on collecting environmental data, such as rainfall, soil $\mathrm{pH}$, temperature, and dew period, and then correlating this information with infection periods or with spore release of target pathogens. Once this correlation is made, pesticides can be applied on an "as-needed" basis. The primary purpose of such fungicide scheduling programs is to time fungicide applications so they occur when actually needed and to eliminate "insurance" sprays. In many cases, this procedure results in an average reduction in fungicide use per season (Jurchak et al., 1983). Occasionally, during periods of highly favorable environmental conditions for disease, fungicide applications may be needed at shorter intervals, resulting in a net increase in the number of fungicidal applications.

\section{Forecasting models}

The earliest models and computerization of these models were the apple scab and the potato late blight models developed at Cornell Univ., Ithaca, N.Y. and Michigan State Univ., East Lansing (Hamilton, 1931; Jones et al., 1980; Krause et al., 1975). However, several new models have been developed for vegetable production and are now routinely used in certain production areas. The first, developed at Pennsylvania State Univ., University Park, forecast Alternaria solani on tomato (FAST) (Pennypacker et al., 1983). The second, to be discussed in detail, is the onion leaf blight (Botrytis squamosa) predictor developed at Michigan State Univ. by M. Lacy (unpublished data). One of the unique aspects of this system is that it anticipates spore release so that fungicides can be applied and be in place before infection periods. Most currently available predictor models, such as for apple scab or blite-cast for potato late blight, define an infection period that has already occurred and systemic fungicides with "back-action" are required for control. The onion leaf blight model predicts the onset of spore release so that a potential infection period can be anticipated (Lacy and Pontius, 1983). The capability of Lacy's model to anticipate infection periods makes it significant because it allows growers to use a broad spectrum of protestant fungicides, whereas most other models must rely on systemic fungicides that have some post-infection eradicant action. Further, other predictor models for onion leaf blight only initiate the program (Vincelli and Lorbeer, 1988). As the Lacy model can accurately predict periods of large spore release, spray applications need not be continuous after the first application.

Several vital data collected on the Botrytis organism that were instrumental in development of the model were 1) B. squamosa sporulates only on dead or dying tissue (Sutton et al., 1978), 2) Botrytis sporulates at 8 to $24 \mathrm{C}$ after 48 to $72 \mathrm{hr}$ of continued high humidity (90\% or more) (Alderman and Lacy, 1984), and 3) spore release correlates highly to infection periods (Sutton et al., 1986). 
These data have now been fed into algorithms in a field weather station containing weather sensors and a microprocessor that will forecast the risk of an infection period. A grower can check his computer field station daily and make a decision on whether to spray.

In field tests conducted in Michigan from 1982 to 1986, a minimum of two and a maximum of six fungicide sprays per season were saved over regular calendar applications (M.L. Lacy, unpublished data). Based on a per-hectare cost of $\$ 4$ for each application, the predictor offers an average seasonal savings to growers of $\$ 16$ per ha per season. With $\approx 3200$ ha of onions grown in Michigan, this represents a potential savings of $\$ 320,000$ annually for Michigan growers. The model has been tested in commercial fields in the two other major northern onion-growing states-New York and Wisconsin. As these states have a combined onion production of $\approx 10,100$ ha, the onion leaf blight predictor could save growers $\$ 1,250,000$ annually.

Funding for development and computerization of disease prediction forecasters has been coming from several sources. In most cases, either the interested commodity group or federal or regional integrated pest management funds have supported development of the model. High-technology companies and computer companies have supported the computerization step.

It is obvious that modeling can fine-tune pesticide application to restrict use to actual need. In general, modeling has allowed effective control of plant pathogens with reduced pesticide usage. I hope that forecasters for more crops will be available in the future. Furthermore, encouragement should be given to develop forecasters that predict more than one disease on a crop. There may be several key foliar diseases on one crop, and the whole purpose of the forecaster could be defeated if growers have to spray routinely for a pathogen for which a forecaster is not available. In Wisconsin, Stevensen has added early blight to the late blight of potato forecaster (Pscheidt and Stevenson, 1980). Lacy has already added downy mildew to his onion disease forecaster, and is currently working on the addition of a purple blotch model, (personal communication). These are important foliar diseases of onion. Additional research in this area will focus on making the field predictor stations more comprehensive in delivering pesticide spray information. Ideally, all of the important diseases and insect pests of a particular crop would be included.

\section{Future approaches}

New, improved or more specialized methods of controlling pests are the culmination of many years of research effort. Presently, novel ideas or concepts in plant pathology are being researched at the basic level and may contribute to alternative pest control solutions in the next century. The concepts include the use of Agrobacterium-mediated transformation in a pathogen-derived resistance approach; protoplasm fusion and somatic hybridization; selection of disease resistance at the cellular level; hypovirulence; and superactive biocontrol agents.

Agrobacterium-mediated transfomation. Resistance genes present in either wild or cultivated plant species have been used intensively in classical plant breeding. However, to be used for genetic engineering, the respective gene has to be cloned, which requires knowledge about the genetic organization and biochemical product of the gene. Currently, little is known regarding the products coded for by plant resistance genes (Willmitzer, 1987). Locating and cloning resistance genes is complicated by the fact that most plant species have large genomes, a large amount of repetitive DNA, and are not well-mapped (Meyerowitz and Pruitt, 1985). Thus, classical molecular cloning techniques do not now look very promising for the physical isolation and use of a resistance gene (Willmitzer, 1987). However, there exists a promising alternative molecular approach to obtaining a form of resistance to some virus diseasesuse of pathogen-derived resistance (Sanford and Johnston, 1985). Rather than relying on host-encoded genes to confer disease resistance, the genome of certain viruses can be used as a source of resistance genes, thus the term "pathogen-derived resistance" (Sanford and Johnston, 1985). This approach is based on the principle that, in any given set of host-pathogen interactions, there are certain pathogen-encoded functions that are essential to the pathogen, but not to the host, and these functions must occur in a certain order. If one of these pathogen-specific functions is altered, the pathogenic process can be stopped or slowed.

Briefly, the method involves isolation and cloning of the viral coat protein encoding region from the pathogenic virus genome, and then incorporating that region into the chromosome of the host plant. Disease resistance appears to result from disrupting the pathogen's life cycle with a pathogen product that is expressed at the wrong time, in the wrong amount, or in a counterfunctional form. Two obvious potential advantages of this approach over the use of host-derived resistance genes are: a) the source of resistance genes would never be in question as the genome of each pathogen would provide resistance genes, and b) since pathogens generally have smaller genomes and shorter life cycles than their hosts, the isolation of such genes should be simpler (Grumet et al., 1987).

Genetically engineered pathogen-derived resistance has been demonstrated in several plant systems. In the past 3 years, a variety of examples have been reported using various approaches. Several groups have demonstrated that expression of viral capsid genes by the host results in reduced susceptibility to virus infection. Examples include tobacco mosaic virus (Powell-Abel et al., 1956), tobacco streak virus and tobacco rattle virus (VanDunn and Bol, 1988; VanDunnet al., 1988), and cucumber mosaic virus (Tumer et al., 1988).

Protoplasm fusion and somatic hybridization. Wide hybridization, between related but distinct species and genera, normally fails because of fertilization failure, embryo lethality, or disruption of embryo-endosperm relations. Hundreds of interspecific and intergeneric gene transfers have been made, with varying degrees of difficulty and with or without various aids such as embryo cultures, grafting techniques, autotetraploid parental lines, bridging crosses, and somatic hybridization. The genes transferred have nearly always been disease-resistance genes (Knotty and Dvorak, 1976).

Somatic cell fusion has extended the range of wide hybridization far beyond the limits of previous techniques. For instance, more than 50 interspecific and intergeneric somatic hybrids have been recovered (Binding, 1985).

Plant pathologists view somatic hybridization as a promising way of circumventing sexual incompatibility barriers and permitting the introgression of valuable germplasm of one species to another, specifically disease resistance genes. However, the difficulties of selecting out the heterokaryons have slowed progressive use of this technique. However, heterokaryon selection using metabolic inhibitors has been quite successful in plant cell fusion studies (Nehls, 1978). Recently, the use of iodacetamide (IOA) proved effective in recovering somatic hybrids between Brassica oleracea L. and $B$. campestris L. at a highly efficient recovery of $90 \%$ (Terada et al., 1987). Use of IOA and other means of effectively recovering heterokaryons may have a considerable impact in the use of somatic hybridization as a means of regenerating disease-resistant germplasm.

Selection of disease resistance at the cellular level. Screening for resistance at the cellular level offers some unique advantages. Large amounts of germplasm can be screened in a short time, selection from a wide variation in disease resistance existing within cells of a horticulturally desirable cultivar may be possible, and the technique may allow for recovery of a new type of resistance. Plant pathologists have used two types of agents of known importance in the disease reaction as a method of screening protoplasts for resistance: toxins and viruses isolated from plant pathogens. The attraction of the toxin system is that uniform exposure of the cells to the selecting agent can be accomplished by dispersing cells in a toxin solution. The toxin approach has been discouraging, because evaluating resistance of most toxin-selected germ plasm taken to the field has been difficult to interpret (Daub, 1986). Another problem with this approach is that it requires some evidence for the role of the toxin in disease. The system suffers from the lack of sufficiently characterized toxins that play an important role in plant disease.

Some technologocial breakthroughs using virus infection technology make selection of disease-resistant germplasm somewhat 
more promising. Inability to achieve high efficiency of infection of protoplasts by the virus has been a major limitation. However, electroporation, a technique recently adapted to achieve viral uptake in protoplasts, has been able to yield $>95 \%$ uptake (Nishiguchi et al., 1986; Watts et al., 1987). Electroporation appears to induce permanent changes in a membrane, thus allowing greater viral ingress during the period of the electrical, charge.

Hypovindence. Hypovirulence refers to the loss or diminution of pathogenic ability in a particular parasitic organism. Several examples are known in which the debilitated strain is able to compare with and dominate virulent forms of the same parasite (Dubos, 1987). Chestnut blight, caused by Endothia parasitica, is controlled in Europe naturally by spread of the hypovirulent strains of the Endothia organism. The hypovirulent strains carry virus-like double-stranded RNAs that limit pathogenicity. The dsRNAs apparently pass through mycelical anastomosis from the hypovirulent to the virulent strains; the latter are rendered hypovirulent as the development of the cankers slows or stops (Agrios, 1988). In France, individual Endothia cankers are being artificially inoculated with a hypovirulent strain by punching holes in the actively developing cankers and introducing inoculum of the hypovirulent strain (Dubos, 1987). Inoculations performed in this way are slow, costly, and could not be used for large groves of trees. Recent research at Michigan State Univ. has shown that cultures of a hypovirulent strain of Endothia in petri plates filled with media and placed on chestnut trees allowed dispersal of the hypovirulent strain throughout a grove and recovery of most trees (D.W. Fulbright, personal communication). If spore dispersal in an aerial form could be achieved, this may be an economical way of applying this biocontrol agent. It is possible that hypovirulent strain of important pathogens of vegetables exist and could be used as biocontrol agents in vegetable production systems.

Super-active biocontrol agents. The use if fluorescent pseudomonades as biocontrol agents has already been discussed. The first registered biofungicide, Dagger $\mathrm{G}$, is believed to compete for $\mathrm{Fe}$ with the target pathogen as well as to produce antibiotics. This example illustrates that the success of a biocontrol agent can be enhanced considerably if it possesses several mechanisms to reduce pathogen activity. Genetic engineering offers the potential of isolating gene coding for the lytic functions and reintroducing them into lytic antagonists to produce a superactive biocontrol agent (Chet, 1987).

It is known that plants are capable of excreting enzymes that degrade fungal and bacterial cell walls. Two such enzymes studied have been chitinase (EC 3.2.1.14) and $\beta$-1,3-glucanase (EC 3.2.1.6). The production of these enzymes by plants is viewed as part of the plant's defense system against pathogens, although the specific substrates of plant origin that can be attacked by chitinase are not wellunderstood. Recently, the chitinase gene for a Serratia sp. has been transferred to a Pseudomonas strain, which then became chitinolytic (Jones et al., 1984). Currently, it is not known if strains possessing lytic enzyme activity can be used to actively degrade the cell wall of plant pathogens. However, if further research demonstrates pathogen cell wall degradation, the addition of a gene coding for a lytic function, such as chitin degradation, could greatly enhance the effectiveness of a biocontrol agent by giving it significantly greater abilities against the target pathogen.

\section{Literature Cited}

Agrios, G.N. 1988. Plant pathology. 3rd ed. Academic, San Diego.

Alderman, S.C. and M.L. Lacy. 1984. Influence of leaf position and maturity on development of Botrytis squamosa in onion leaves. Phytopathology 74:1461-1463.

Baker, R. and F.M. Scher. 1987. Enhancing the activity of biological control agents, p. 1-18. In: L Chet (ed.). Innovative approaches to plant disease control, Wiley, New York.

Barden, K. A., S.S. Smith, and H.H. Murakishi. 1986. Regeneration and screening of tomato somaclones for resistance to tobacco mosaic virus. Plant Sci. 45:209-213.

Binding, H. 1985. Regeneration of plants, p. 21-37. In: L.C. Fawke and F. Constable (eds.). Plant protoplasts. CRC Press, Boca Raton, Fla. Biocontrol Committee. 1988. Amer. Phytopathol. Soc., Biocontrol Nwsl. $1(2)$.
Brosten, D. 1988. In-furrow biological fungicide set to protect seedlings from disease. Agrichem. Age, June. p. 10-12.

Brown, C., J.A. Lucas, I.R. Crute, D.G.A. Walkey, and J.B. Power. 1986. An assessment of genetic variability is somaclonal lettuce plants(Lactuca sativa) and their offspring. Ann. Applied Biol. 109:391-407.

Chet, I. 1987. Trichoderma-application; mode of action and potential as a biocontrol agent of soil borne plant pathogenic fungi, p. 137-160. In: I. Chet (ed.). Innovative approaches to plant disease control. Wiley, New York.

Chet, I., G.E. Harman, and R. Baker. 1981. Trichoderma hamatum: Its hyphal interactions with Rhizoctonia solani and Pythium spp. Microbiol. Ecol. 7:29-38.

Cook, R.J. 1981. Biological control of plant pathogens: Overview, p. 2344. In: G.C. Papavizas (ed.). Biological control in crop production (BARC Symp. 5), Allanheld, Osmem Totowa, N.J.

Daub, M.E. 1986. Tissue culture and the selection of resistance to pathogens. Annu. Rev. Phytopathol. 24:159-186.

Dubos, B. 1987. Fungal antagonism in aerial agrobiocenoses, p. 107-136. In: I. Chet (ed.). Innovative approaches to plant disease control. Wiley, New York.

Elad Y., Y. Hadar, I. Chet, and Y. Hen is. 1982. Prevention with Trichoderma harzianum Rifai aggr of reinfestation by Sclerotium rolfsii Sacc. and Rhizoctonia solani Kuhn of soil fumigated with methylbromide and improvement of disease control in tomatoes and peanuts. Crop Protect. 1:199-211.

Garroway, M.D. and R.C. Evans. 1984. Fungal nutrition and physiology. Wiley, New York.

Grumet, R., J.C. Sanford, and S.A. Johnston. 1987. A demonstration of pathogen-derived resistance using Escherichia coli and the bacteriophage Q-beta, p. 3-12. In: C. Arntzen and C. Ryan (eds.). Molecular strategies for crop protection. UCLA Symp. on Cellular and Molecular Bio. vol. 48. Liss, New York.

Hamilton, J.M. 1931. Studies of the fungicidal action of certain dusts and sprays in the control of apple scab. Phytopathology 21:445-523.

Jones, A. L., S.L. Lillevik, P.D. Fisher, and T.C. Stebbins. 1980. A microcomputer-based instrument to predict primary apple scab infection periods. Plant Dis. 64:69-72.

Jones, J., J.S. Ziegle, and T.V. Suslow. 1984. Cloning and expression of Serratia chitinasc genes in E. coli and Pseudomonas rhizobacteria. Phytopathology 743:863.

Jurchak, T. A., A.A. MacNab, and S.P. Pennypacker. 1983. Detect tomato early blight fast. Amer. Veg. Grower. Nov. p. 41.

Krause, R. A., L.B. Massic, and R.A. Hyrc. 1975. Blite cost; a computerized forecast of potato late blight. Plant Dis. Rptr. 59:95-98.

Knotty, D.R. and J. Dvorak. 1976. Alien germplasm as a source of resistance to disease. Annu. Rev. Phytopathol. 14:211-235.

Lacy, M.L. and G.A. Pontius. 1983. Prediction of weather-mediated release of conidia of Botryfis squamosafrom onion leaves in the field. Phytopathology 73:670-676.

Larkin, P.J. and W.R. Scowcroft. 1981. Somaclonal variation-a novel source of variability from cell cultures for plant improvement. Theor. Applied Genet. 60:197-214.

Lifshitz, R., B. Sneh, and R. Baker. 1984. Soil suppressiveness to a pathogenic Pythium species. Phytopathology 74:1054-1061.

Meyerowitz, E.M. and R.E. Pruitt. 1985 Arabidopsis thaliana and plant molecular genetics. Science 229:1214-1218.

Nehls, R. 1978. The use of metabolic inhibitors for the selection of fusion products of higher plant protoplasts. Mol. Gen. Genet. 166:117-118.

Nishiguchi, M., W.H.R. Langridge, A.A. Szalay, and M.M. Zaitlin. 1986. Electroporation-mediated infection of tobacco leaf protoplasts with tobacco mosaic virus RNA and cucumber mosaic virus RNA. Plant Cell Rptr. 5:57-60.

Papavizas, G. C., J.A. Lewis, and T.N. Abd-El Moity. 1982. Evaluation of new biotypes of Trichoderma harzianum for tolerance of benomyl and enhanced biocontrol capabilities. Phytopathology 72:126-132.

Pennypacker, S. P., L.V. Madden, and A.A. McNab. 1983. Validation of an early blight forecasting system for tomatoes. Plant Dis. 67:287-289.

Powell-Abel, P. P., R.S. Nelson, B. De, N. Hoffmann, S.G. Rogers, R.T. Fraley, and R.N. Beachy. 1956. Delay of disease development in transgenic plants that express the tobacco mosaic virus coat protein gene. Science 232:738.

Pscheidt, J.W. and W.R. Stevenson. 1980. Comparison of forecasting methods for control of potato early blight in Wisconsin. Plant Dis. 70:915920.

Rothrock, C.S. and D. Gottlieb. 1984. Role of antibiosis in antagonism of Streptomyces hygroscopicus var. geldanus to Rhizoctonia solani in soil. Can. J. Microbiol. 30:1440-1447.

Sanford, O.C. and S.A. Johnston. 1985. The concept of parasite-derived resistance-deriving resistance genes from the parasite's own genome. J. Theor. Biol. 113:395. 
Scher, D.I. and R. Baker. 1980. Mechanisms of biological control in a Fusarium-suppressive soil. Phytopathology 70:412-417.

Suslow T.V. and M.W. Scroth. 1982. Rhizobactcria of sugar beets: Effects of seed application and root colonization on yield. Phytopathology 72:199206.

Sutton, J. C., C.J. Swanton, and T.J. Gillespie. 1978. Relation of weather variables and host factors to incidence of airborne spores of Botrytis squamosa. Can. J. Bet. 56:2460-2469.

Sutton, J. C., T.D. James, and P.M. Rowell 1986. BOTCAST: A forecasting system to time the initial fungicide spray for managing Botrytis leaf blight of onions. Agr. Ecosyst. Environ. 18:123-143.

Terada, R., Y. Yamashita, S. Nishibayashi, and K. Shimamoto. 1987. Somatic hybrids between Brassica oleracea and B. campestris: Selection by the use of iodoacetamide inactivation and regeneration ability. Theor. Applied Genet. 73:379-384.

Turner, W., K. O'Connell, M. Cuozzo, W. Kaniewski, and N.H. Chua. 1988. Analysis of protection in transgenic plants expressing the cucumber mosaic virus coat protein or its antisense RNA. J. Cell Biochem. 12C:292.
(Suppl.)

VanDunn, C.M.P. and J.F. Bol. 1988. Tobacco plants accumulating tobacco rattle virus coat protein resist infection with tobacco rattle virus and pea early browning virus. Virology 167:649-652.

VanDunn, C. M. P., B. Overduin, L. van Vloten-Doting,. and J.F. Bol. 1988. Expression of viral cDNA in transgenic plants and cross-protection. J. Cell Biochem. 12C:298. (Suppl.)

Vincelli, P.C. and J.W. Lorbeer. 1988. Forecasting spore episodes of Botrytis squamosa in commercial onion fields in New York. Phytopathology 78:966-970.

Watts, J. W., J.M. King, and W.J. Stacy. 1987. Inoculation of protoplasts with viruses by electroporation. Virology 157:40-46.

Willmitzer, L. 1987. Genetic engineering for plant resistance, p. 353-364. In: L Chet (ed.). Innovative approaches to plant disease control. Wiley, New York.

Wright, J.C. and M.L. Lacy. 1988. Increase of disease resistance in celery cultivars by regeneration of whole plants from cell suspension cultures. Plant Dis. 72:256-259.

\title{
Minimal Use of Synthetic Fertilizers in Vegetable Production
}

\author{
William C. Kelly \\ Department of Vegetable Crops, Cornell Universiy, Ithaca, NY 14853
}

There has been a dramatic increase in the use of synthetic chemicals, especially $\mathrm{N}$ fertilizers, since 1945 , with a concomitant increase in the production of vegetables. These products, together with new mechanical technology, have led to a high degree of specialization in vegetable growing and the plentiful supply of cheap $\mathrm{N}$ fertilizer has permitted intensive use of the soil.

The popular press and conservation-type organizations have vigorously campaigned against the use of synthetic fertilizer for various reasons. Agriculture has been urged to use less synthetic fertilizer, but growers have not responded by reducing fertilizer rates. The purpose of this article is to consider some of the reasons claimed for reducing fertilizer and to consider alternate ways of fertilizing vegetables.

Conservation of fossil fuel is one reason to reduce synthetic $\mathrm{N}$ use, but the farmer does not sense any urgency in reducing fertilizer while urban neighbors use large quantities of fossil fuel in recreational activities. Some organic gardening proponents eschew all synthetic materials and contend that continued use of synthetic fertilizers lowers the nutritive value of food. This cannot be supported by scientific evidence, except in a few cases of high nitrate levels in leafy vegetables resulting from excessive application of N. Nitrates also accumulate in plants grown on excessive quantities of animal manures.

The low cost of fertilizer, compared to other inputs, encouraged liberal use of fertilizer, as indicated by a steady increase in $\mathrm{P}$ and, in some soils, $\mathrm{K}$ during the 35 years of my experience with soil testing on vegetable farms in New York. There was no reliable soil test for N, but it was applied just as liberally as P and K. From the soil test data, it is apparent that fertilizer rates could be reduced without reducing yield of most vegetables, but the risk outweighed the benefits for most vegetable growers.

The most pressing reason for reducing rates of inorganic fertilizers, well-documented, is the pollution of ground water with nitrate and of lakes and streams with nitrate and $\mathrm{P}$ (Porter ${ }_{\mathrm{j}}$ 1975). The solution to these problems seems to lie in a reduction in the use of synthetic N. Large quantities of fossil fuel are expended in manufacturing $\mathrm{N}$ fertilizer. While $\mathrm{NH}_{3}$ ions are absorbed on the cation exchange complex in the soil, they are eventually nitrified to nitrate, which may be taken up by the plant, leached below the root zone, or denitrified to become a part of the air pollution problem. Even the $\mathrm{P}$ pollution of streams is mostly the result of cheap synthetic $\mathrm{N}$ that permitted intensive use of the land and increased the erosion of P-rich topsoil. Can we reduce the use of synthetic $\mathrm{N}$ and maintain a competitive and profitable vegetable industry?

\section{Other sources of nitrogen}

Before synthetic $\mathrm{N}$ was available, organic $\mathrm{N}$ sources, mostly industrial by-products, were the basis of the chemical fertilizer industry. An important source was by-products from meat packing, i.e., tankage, meat scrap, and dried blood. These have all become important protein sources for feeds, especially pet foods, and are now too expensive to use as fertilizer and are in short supply.

Seed meals, such as cottonseed meal, were useful as conditioners and $\mathrm{N}$ sources in mixed fertilizer, but they are low in $\mathrm{N}$ content and cannot be used in high-analysis fertilizers. There are also competing uses for such materials, which keeps the cost high.

Sewage sludge was once thought to be useful as a fertilizer, but the presence of toxicants such as $\mathrm{Cd}$ make it suspect for use on food and feed crops. Also, the nutrient content is low and slowly available. Municipal comporting has been suggested as a means of disposing of the garbage and producing a marketable product. Again, the nutrient composition is low and variable and few cities have adopted the program. Sludge and compost have the same disadvantage of great bulk, which makes transportation and application difficult and expensive.

\section{Animal manures}

Animal manures were the basis of vegetable growing until the automobile replaced the horse. The intensive vegetable industry around cities depended on the plentiful supply of horse manure as a source of fertilizer and as a source of heat for their hotbeds. The extensive production of potatoes and processing crops occurred on dairy or general farms as a cash crop and used manure produced on the farm. Most of today's vegetables are grown on specialized and highly mechanized farms using synthetic fertilizers with most, if not all, of the income from the sale of vegetables. There is no doubt that high yields of vegetables can be produced with manure and minimal use of chemical fertilizers. The question is one of management and profitability.

Manures are not produced on vegetable farms, so where can a grower find an available supply? Dairy farms use all the manure they produce on their own crops. Feed lots are not common in New York, but poultry enterprises are possible sources of manure, since they seldom produce the feed used. Horse manure may be seasonally available at racetracks or riding stables.

Distance from the farm is the critical factor in the decision to use manure, since it is bulky material of low fertilizer value. Equipment for loading is needed at the source and at the farm. Manure spread- 